
\title{
\& Research Square \\ Diversity of Streptomyces spp. in desert and savanna soils in Sudan
}

\section{Mohamed EHAMID ( $\square$ mehamid3@gmail.com )}

King Khalid University https://orcid.org/0000-0003-0085-827X

\section{Adil Mahgoub}

University of Khartoum

Abderaham J. Osman

Omdurman Islamic University

Hussein A Elhussein

University of Khartoum

Mohammed A.I. Holie

Alzaiem Alazhari University

Mogahid M Elhassan

Taibah University

Martin R.P. Joseph

King Khalid University

\section{Research note}

Keywords: Actinomycetes, ecosystem, biodiversity, phenotypic identification, 16S rRNA gene.

Posted Date: October 16th, 2019

DOI: https://doi.org/10.21203/rs.2.16084/v1

License: (c) (1) This work is licensed under a Creative Commons Attribution 4.0 International License.

Read Full License 


\section{Abstract}

Objective The purpose of this study was to investigate streptomycete populations in desert and savanna ecozones in Sudan and to identify species diversity on the basis of 16S rRNA gene sequence analysis.

Results A total of 49 different Streptomyces phenotypes (23 from sites representing the desert and semidesert zone; 26 representing the Savanna zone) have been included in the study. The isolates were characterized phenotypically and confirmed using 16S rRNA analysis. The two zones showed similarities and uniqueness in the types of isolates. Shared species were: Streptomyces werraensis, S. enissocaesilis, S. leeuwenhoekii -like, but desert zone revealed unique species such as S. griseostramineus, S. chromofuscus - like and S. prasinosporus. Whereas, the savanna zone revealed unique species such as S. albogriseolus, S. djakartensis, S. chilikensis and S. variabilis . Streptomycetes are widely distributed in both desert and the savannah ecozones and most of them require full descriptions. Extending knowledge on Streptomyces communities and their dynamics in different ecological zones for health and production benefits is needed.

\section{Introduction}

The phylum Actinobacteria hosts diverse high G+C, Gram-positive bacteria including members of the genus Streptomyces. Streptomycetes are gram-positive spore forming bacteria in the-phylum Actinobacteria (order Actinomycetales) which include more than 900 species (https://www.ncbi.nlm.nih.gov/Taxonomy/Browser/wwwtax.cgi?id = 1883). Streptomyces represent the largest taxonomic group within the domain Bacteria which is ubiquitously distributed in both aquatic and terrestrial ecosystems $[1,2]$. They are found in a wide range of habitats but particularly abundant in soil representing around 1 to $20 \%$ of the total viable count $[2,3]$ and known to confer the characteristic earthy smell (geosmin) [4]. Streptomycetes are chemoheteroorganotrophs and distinguished by their tough, leathery colonies and filamentous growth. They have an important ecological role in the turnover of organic material and capable of using complex organic materials like carbon and energy sources and are involved in the breakdown of these products in the soil [5].

The microbial communities including streptomycetes are affected by biotic and abiotic factors notably vegetation, type of soil and climate. Actinomycetes diversity particularly streptomycetes is widely documented for various reasons including the continued generation of environmental isolates for pharmaceutical, biodegradative, and biotechnological screening. Actinomycetes isolated from soil and related substrates show primary biodegradative activity [5].

Exploring new habitats around the globe are becoming increasingly the focus for discovering new taxa of Actinobacteria, namely streptomycetes. These can be a likely new source of metabolites with various biological activities, such as antibacterial, antitumoral and antifungal [6]. Unexplored soil habitats of forest ecosystems in India were found to contain novel Actinobacteria species [7]. The habitat of Sudan has likewise remained untouched except a very few studies. Some areas in Sudan were found rich 
sources of microbial biodiversity holding within it immense novelty and potentiality of identifying new isolates for production of life-saving drugs such as amphotericin A. Marine habitat of Sudan was found a promising for Streptomyces spp., culture enhancing the authors said may influence the production of secondary metabolites [8] Two actinomycin D producing streptomycetes from Sudanese soil have been characterized and were found different from previously actinomycin producing species [9]. The finding of distinct phylogenetic lineages and the variation in the spatial distribution of clones suggests that selection pressures may vary over the soil-landscape [10].

This study aimed to isolate and identify streptomycetes from in desert and savanna zones in Sudan and to find out the species diversity in the two zones using $16 \mathrm{~S}$ rRNA gene analysis.

\section{Methods}

\section{Study site and sampling}

Soil samples were collected sites in two ecozones; zone 1 was the desert and the semi-desert and zone 2 was the low rainfall woodland savanna. The ecological zones were based on the ecological classification by Harrison and Jackson's [11].

The soil samples were collected during the dry season from the surface as well as $5-10 \mathrm{~cm}$ depth. $10 \mathrm{~g}$ from five sections within each site were collected with a sterilized spatula. Soils were then merged, sieved and thoroughly mixed. The composite sample was transferred into sterile plastic bags, labeled, transported to the laboratory and stored at $4{ }^{\circ} \mathrm{C}$ awaiting analysis.

Soil type in the desert (sites 7 and 19) is Yermosol \{Jones, $2013 \# 13186\}$ with an average annual temperature $29.7^{\circ} \mathrm{C}$ and an average annual rain of $70 \mathrm{~mm}$. Savanna (sites $\left.8.10 .14,23,29\right)$ have the following soil types: Arenosols (Stabilized sand dunes with silt or clay) in sites $8,10,14$, and 23; whereas site 29 (Ad Damazin; $11.7855^{\circ} \mathrm{N} ; 34.3421^{\circ} \mathrm{E}$ )) has Vertisols soil type. Savanna sites have annual temperatures range from 26.0 to $28.5^{\circ} \mathrm{C}$ and annual rains range from 213 in Al Fashir $\left(13.6198^{\circ} \mathrm{N}\right.$; $25.3549^{\circ} \mathrm{E}$ ) to $713 \mathrm{~mm}$ in Ad Damazin (site 29).

\section{Isolation of Streptomyces spp.}

Higher nitrogen content (HNC) medium [13] was used as a pretreatment method to assist the extraction and isolation of streptomycetes. $\mathrm{HNC}$ medium was prepared and store at $4^{\circ} \mathrm{C} .0 .5 \mathrm{grams}$ of a soil sample was added to $50 \mathrm{ml} \mathrm{HNC}$ medium in a sterile Erlenmeyer flask. Flasks were placed on a shaker at $42^{\circ} \mathrm{C}$ for 1 hour. The suspension was left for 5 minutes and transferred to a clean Falcon tube.

ISP2 agar [14] supplemented with cycloheximide $(50 \mu \mathrm{g} / \mathrm{ml})$, nystatin $(40 \mu \mathrm{g} / \mathrm{ml})$ and nalidixic acid $(54.9 \mathrm{ug} / \mathrm{mL})$ and $1 \mathrm{ml}$ vitamin solution (filtered stock solution in $80 \mathrm{~mL} \mathrm{DW}$. pH 7: folate, $1 \mathrm{mg}$ [(0.0125 ug/ml); biotin, $1 \mathrm{mg}(0.0125 \mathrm{ug} / \mathrm{ml}) ;$ p-aminobenzoic acid, $20 \mathrm{mg}(0.25 \mathrm{ug} / \mathrm{ml})$; thiamine, $\mathrm{HCl}, 100 \mathrm{mg}(1.25$ 
$\mathrm{ug} / \mathrm{ml})$; pantothenic acid, $120 \mathrm{mg}(1.5 \mathrm{ug} / \mathrm{ml}) ;$ riboflavin, $100 \mathrm{mg}(1.25 \mathrm{ug} / \mathrm{ml})$; nicotinic acid, 230 $\mathrm{mg}(2.875 \mathrm{ug} / \mathrm{ml})$; vitamin B12, $10 \mathrm{mg}((0.125 \mathrm{ug} / \mathrm{ml})]$ was used for the isolation and cultivation of Streptomyces spp. Subsequent to autoclaving and cooling to $40^{\circ} \mathrm{C}$, the medium was supplemented with cycloheximide $(50 \mu \mathrm{g} / \mathrm{ml})$, nystatin $(40 \mu \mathrm{g} / \mathrm{ml})$ and nalidixic acid $(54.9 \mathrm{ug} / \mathrm{mL})$ to inhibit bacterial and fungal contamination.

Samples were diluted as 1:0 (no dilution; $1: 5 ; 1: 10$ and 1:30. From each dilution, $0.1 \mathrm{~mL}$ was evenly spread onto the ISP2 medium using sterile Drigalski spatula. Inoculated plates were incubation at $28^{\circ} \mathrm{C}$ for up to three weeks. Suspected colonies were picked out and streaked onto fresh ISP2 medium to purify streptomycetes colonies [15]. The pure culture were stored on sterile vials containing $20 \%$ glycerol solution at $-20^{\circ} \mathrm{C}$ for further analysis.

\section{Microbial characterization}

The recognized Streptomyces isolates were studied for morphological and microscopic properties using light microscopy [2]. Strains that showed mutual characteristics were clustered to form preliminary Streptomyces color groups for further analysis.

The 16S rRNA was amplified from genomic DNA samples using eubacterial universal primers 27 F 5'AGAGTT TGA TCC TGG CTC AG-3' and 1492R 5'-GGT TAC CTT GTT ACG ACT T-3'[16]. Amplification reactions were performed in a final volume of $20 \mu \mathrm{l}$, containing Promega Green Mix. The thermal cycling conditions were as follows: initial denaturation at $94^{\circ} \mathrm{C}$ for $5 \mathrm{~min} ; 31 \mathrm{cycles}$ at $95^{\circ} \mathrm{C}$ for $30 \mathrm{~s}, 54^{\circ} \mathrm{C}$ for $90 \mathrm{~s}$ and $72^{\circ} \mathrm{C}$ for $120 \mathrm{~s}$; and a final extension at $72^{\circ} \mathrm{C}$ for $5 \mathrm{~min}$. The amplification reaction was performed by Bio-Rad thermal cycler (MyCycler, Bio-Rad, USA) and the amplified products were examined by $1 \%$ agarose gel electrophoresis.

16S rRNA gene amplification and determination of the almost complete sequence were performed as described by Rainey et al. [17]. For 16S rRNA gene sequencing, chromosomal DNA was isolated from a 7 day culture PEG 200 (polyethylene glycol, Sigma-Aldrich). PCR-mediated amplification of the 16S rRNA gene and DNA sequencing were carried out with two universal primers, 27F (5'AGAGTTTGATCCTGGCTCAG-3') and 1492R (5'-TACGGTTACCTTGTTACGACTT-3') [18]. The ABI 370XL 96-capillary DNA analyzer (Applied Biosystems) and SeqMan software (DNASTAR) were used to analyze and assemble the gene sequences.

Obtained DNA sequences were aligned with other reference sequences available in the GenBank database using BLAST. Alignments were inspected visually. Then sequences were analyzed phylogenetically by the neighbor-joining method [19] using MEGA software. [20]

\section{Results}


A total of 49 different Streptomyces phenotypes (23 from sites representing the desert and semi-desert zone; 26 representing the Savanna zone) were recovered and identified. Various bacterial colonies appeared on ISP2 agar after 3 days of aerobic incubation at $28^{\circ} \mathrm{C}$ (Fig. 1). Separation and purification of colonies by using pick spot technique on ISP2 agar master plates were used to purify and store colony mass for further analysis.

As a result of 16S rRNA gene sequencing, all 49 strains were confirmed as Streptomyces spp. Nucleotide sequence data have been deposited in GenBank and corresponding accession numbers are listed in Table 1. Isolate sequences were compared with sequences of Streptomyces type strains, and the relationships between the isolates and their closest phylogenetic neighbors are shown in Figure 2. Some sequences formed distinct phylogenetic lines, while others were grouped in clusters in the Streptomyces 16S rRNA gene tree.

Both desert and savanna soils showed similarity in the number of isolates in the following clusters: Cluster 1: Streptomyces werraensis; Cluster 5: Streptomyces enissocaesilis; Custer 7: Streptomyces sp. (S. leeuwenhoekii-like); Cluster 2: Streptomyces sp. (S. levis-like); and Cluster 6: Streptomyces sp. (S. misionensis-like). But desert unlike savanna desert and savanna soils showed unique isolation of: 9: Streptomyces griseostramineus; Custer 10: Streptomyces sp. (S. prasinosporus -like); Streptomyces carpinensis-like; Streptomyces cinnabarinus-like; Streptomyces fumanus-like; Streptomyces prasinosporus; and Streptomyces niveoruber -like. On the other hand, savanna soils showed unique isolation of: Cluster 3: Streptomyces albogriseolus; Cluster 4: Streptomyces djakartensis; Cluster 11: Streptomyces sp. (S. deserti -like); Cluster 12: Streptomyces chilikensis; Streptomyces variabilis; Streptomyces lomondensis-like; and Streptomyces pomoeae -like.

Fig. 1 Colony morphology of Streptomyces spp. isolated from desert and savanna soils in Sudan using ISP2 medium, incubated at $280 \mathrm{OC}$ for 15 days (plat number indicated soil sits and letter indicates phenotype).

Fig. 2 Phylogenetic relationships based on 16S rRNA sequences amongst 49 Streptomyces strains in relationship o closely related validly described species. Evolutionary analysis was based on the Neighborjoining method using MEGA7 software [21].

Table 1. Custer analysis of streptomycete populations isolated from desert and savanna zones in Sudan and identified on the basis of 16S rRNA gene analysis. 


\begin{tabular}{|c|c|c|c|}
\hline Cluster & $\begin{array}{l}\text { Strain } \\
\text { code }\end{array}$ & Similarity rate & $\begin{array}{l}\text { GenBank Accession } \\
\text { number }\end{array}$ \\
\hline \multirow[t]{9}{*}{ Cluster 1: Streptomyces werraensis } & $7 \mathrm{E}$ & $98.50 \%$ with S. werraensis & MF356353 \\
\hline & 70 & $99.52 \%$ with S. werraensis & MF356359 \\
\hline & $8 \mathrm{E}$ & 99.70\% with S. werraensis & MF353990 \\
\hline & $10 \mathrm{C}$ & $100 \%$ with S. werraensis & MF353939 \\
\hline & 19D & 99.55\% with S. werraensis & MF356332 \\
\hline & 19| & $100 \%$ with S. werraensis & MF353955 \\
\hline & $19 \mathrm{~J}$ & 99.33\% with S. werraensis & MF356334 \\
\hline & $29 B$ & $99.88 \%$ with S. werraensis & MF353967 \\
\hline & $29 \mathrm{D}$ & 99.63\% with S. werraensis & MF353969 \\
\hline \multirow[t]{5}{*}{$\begin{array}{l}\text { Cluster 2: Streptomyces sp. (Streptomyces } \\
\text { werraensis-like) }\end{array}$} & $7 \mathrm{~A}$ & $\begin{array}{l}97.00 \% \text { with S. griseostramineus } \\
96.73 \% \text { with S. werraensis }\end{array}$ & MF356350 \\
\hline & $7 G$ & $99.10 \%$ with S. werraensis & MF356354 \\
\hline & $14 \mathrm{H}$ & 99.21\% with S. werraensis & MF356328 \\
\hline & 19B & $98.83 \%$ with S. werraensis & MF353953 \\
\hline & 19E & 94.91\% with S. werraensis & MF356333 \\
\hline \multirow[t]{4}{*}{ Cluster 3: Streptomyces albogriseolus } & $8 \mathrm{~A}$ & 99.79\% with S. albogriseolus & MF353987 \\
\hline & $8 \mathrm{~B}$ & $100 \%$ with S. albogriseolus & MF353988 \\
\hline & $8 \mathrm{~F}$ & $99.13 \%$ with S. albogriseolus & MF356361 \\
\hline & $8 \mathrm{H}$ & $99.77 \%$ with S. albogriseolus & MF353991 \\
\hline \multirow[t]{3}{*}{ Cluster 4: Streptomyces djakartensis } & $14 \mathrm{E}$ & $100 \%$ with S. djakartensis & MF353947 \\
\hline & $14 \mathrm{~J}$ & $100 \%$ with S. djakartensis & MF353948 \\
\hline & $14 \mathrm{~K}$ & $100 \%$ with S. djakartensis & MF353949 \\
\hline \multirow[t]{4}{*}{ Cluster 5: Streptomyces enissocaesilis } & $7 \mathrm{~J}$ & 98.44\% with S. enissocaesilis & MF356356 \\
\hline & $7 \mathrm{~K}$ & $\begin{array}{l}100 \% \text { with S. enissocaesilis and } 100 \% \text { with S. } \\
\text { rochei }\end{array}$ & MF353986 \\
\hline & 10B & $\begin{array}{l}\text { 99.30\% with S. enissocaesilis and } 99.30 \text { with } \\
\text { S. rochei }\end{array}$ & MF353938 \\
\hline & 10D & $\begin{array}{l}99.41 \% \text { with S. enissocaesilis and } 99.41 \% \\
\text { with S. rochei }\end{array}$ & MF353940 \\
\hline \multirow[t]{3}{*}{ Cluster 6: Streptomyces sp. } & $14 \mathrm{G}$ & $98.41 \%$ with $S$. hawaiiensis & MF356327 \\
\hline & $19 \mathrm{~K}$ & 98.86\% with S. fimbriatus & MF356335 \\
\hline & $8 \mathrm{~L}$ & $98.32 \%$ with $S$. misionensis & MF356363 \\
\hline \multirow{2}{*}{$\begin{array}{l}\text { Custer 7: Streptomyces sp. (S. } \\
\text { leeuwenhoekii-like) }\end{array}$} & 14D & 98.57\% with S. leeuwenhoekii & MF356326 \\
\hline & $14 \mid$ & $97.89 \%$ with S. leeuwenhoekii & MF356329 \\
\hline \multirow{2}{*}{$\begin{array}{l}\text { Cluster 8: Streptomyces leeuwenhoekii- } \\
\text { like }\end{array}$} & $7 \mathrm{H}$ & 99.77\% with S. leeuwenhoekii & MF353985 \\
\hline & $14 \mathrm{C}$ & 96.83\% with S. leeuwenhoekii & MF356325 \\
\hline \multirow[t]{2}{*}{ Cluster 9: Streptomyces griseostramineus } & $19 \mathrm{H}$ & 99.77\% with S. griseostramineus & MF353954 \\
\hline & $7 \mathrm{~B}$ & 99.89\% with S. griseostramineus & MF353983 \\
\hline \multirow{2}{*}{$\begin{array}{l}\text { Custer 10: Streptomyces sp. (S. } \\
\text { chromofuscus - like) }\end{array}$} & $7 \mathrm{C}$ & 97.63\% with S. chromofuscus & MF356351 \\
\hline & $7 \mathrm{~N}$ & 99.18\% with S. chromofuscus & MF356358 \\
\hline \multirow{2}{*}{$\begin{array}{l}\text { Cluster 11: Streptomyces sp. (S. . } \\
\text { capitiformicae-like) }\end{array}$} & $8 \mathrm{C}$ & 98.03\% with S. capitiformicae & MF356360 \\
\hline & $8 \mathrm{R}$ & 98.03\% S. capitiformicae & MF356365 \\
\hline \multirow[t]{2}{*}{ Cluster 12: Streptomyces chilikensis } & 14B & $\begin{array}{l}98.76 \% \text { with S. chilikensis; } 98.95 \% \text { with S. } \\
\text { fragilis }\end{array}$ & MF356324 \\
\hline & 23B & $\begin{array}{l}98.76 \% \text { with S. chilikensis; } 98.95 \% \text { with S. } \\
\text { fragilis }\end{array}$ & MF353961 \\
\hline Streptomyces carpinensis-like & $7 \mathrm{D}$ & $\begin{array}{l}99.04 \% \text { with S. carpinensi; } 99.33 \% \text { with S. } \\
\text { levis }\end{array}$ & MF356352 \\
\hline Streptomyces chartreusis-like & $29 \mathrm{C}$ & $\begin{array}{l}98.47 \% \text { with S. chartreusis; } 98.48 \% \text { with } S . \\
\text { cinnabarinus }\end{array}$ & MF353968 \\
\hline
\end{tabular}




\begin{tabular}{|l|l|l|l|} 
Streptomyces cinnabarinus-like & 7I & $\begin{array}{l}98.98 \% \text { with S. cinnabarinus; } 99.08 \% \text { with S. } \\
\text { albaduncus }\end{array}$ & MF356355 \\
\hline Streptomyces variabilis & $8 \mathrm{D}$ & $99.90 \%$ with S. variabilis & MF353989 \\
\hline Streptomyces lomondensis-like & $8 \mathrm{~N}$ & $\begin{array}{l}99.37 \% \text { with S. lomondensis and 99.12\% with } \\
\text { S. luteogriseus }\end{array}$ & MF356364 \\
\hline Streptomyces fumanus-like & 19A & $\begin{array}{l}98.82 \% \text { with S. fumanus; } 98.55 \% \text { with S. } \\
\text { leeuwenhoekii }\end{array}$ & MF356331 \\
\hline Streptomyces prasinosporus & 7F & 99.90\% with S. prasinosporus & MF353984 \\
\hline Streptomyces niveoruber -like & 7M & 97.32\% with S. niveoruber & MF356357 \\
\hline Streptomyces pomoeae-like & $8 \mathrm{G}$ & $\begin{array}{l}99.51 \% \text { with S. pomoeae; } 99.51 \% \text { with S. } \\
\text { ossamyceticus }\end{array}$ & MF356362 \\
\hline
\end{tabular}

\section{Discussion}

Streptomycetes are widely distributed in nature especially in soils with different structures and chemistry. This study was undertaken to highlight the presence of streptomycetes in two types of ecosystems and identify isolates to species levels. The results indicate the similarity in the types of isolates and the uniqueness of each ecosystem as Savanna revealed species that are not present in the desert soil. These findings emphasize the value for more analysis towards getting novel antimicrobial agents from these streptomycetes from either desert or savanna zones. Few scientific works have been carried out in this field notably in the distinctive ecosystems of Sudan.

In many sub-Saharan African countries including Sudan, have considerable diverse soils, such as clay in the east-central area and sand dunes in the west and north with variable climatic conditions [22]. Comparing the isolates, site-dependent patterns related to the ecoregion-specific soil type and annual rainfall were noticed. S. griseostramineus, S. chromofuscus - like and S. prasinosporus were isolated from desert but not from Savanna. Likewise, the savanna zone, supposedly rich soil for agriculture, disclosed distinctive species such as S. albogriseolus, S. djakartensis, S. chilikensis and S. variabilis. Many other single member clusters have been found in both zones, many of them not fully identified as potential novel species giving their significant nucleotide dissimilarity with all know Streptomyces spp. similar results from desert and semi-desert soils in areas in Israel, which were related to specific environmental factors rather than to geographic distances and spatial distribution patterns [23].

These findings are similar to those reported from Atacama Desert in Chile where distinguished clades of Streptomyces pp. These were found with a widespread range of antibacterials and differing modes of action have been isolated from the Atacama desert [24]. The forces controlling desert ecosystem degradation rates are poorly understood, particularly concerning relevance of the arid-soil microbiome. Neilson et al. [25] distinguished important environmental and geochemical factors that model the arid soil microbiome along aridity and vegetation gradients spanning over $300 \mathrm{~km}$ of the Atacama Desert, Chile. Decreasing average soil relative humidity and increasing temperature explain significant reductions in the diversity and connectivity of these desert soil microbial communities and lead to significant 
reductions in the abundance of key taxa typically associated with fertile soils [25] as we have seen in the savanna soils examined in the present study.

In summary, we have effectively isolated and identified several streptomycetes from two different ecozones. A notable percentage of these isolates fit in uncommon species and some may represent new species. We believe the information provided will be of use to the Streptomyces researchers.

\section{Limitations}

- Microorganisms in soils are exposed to different stress factors: chemical, physical and biological. Of these variable conditions, sometimes nutrients can be limited, preventing growth [1].

- Given the unusual climatic conditions, the desert has been believed to home for unique potential Streptomyces which are mostly yet to be discovered. Our finding indicates the richness of the desert soil in revealing many species in major clusters but sample sites were limited.

- An acquaintance of knowledge on Streptomyces communities and their dynamics in different ecological zones for health, biotechnology and agricultural benefits still need to be explored. Desert habitats are remarkably rich in species of the Actinobacteria class. This richness is not inevitably extensive in taxonomic diversity [24].

\section{Declarations}

\section{Acknowledgments}

Authors wish to thank the staff at the UFZ, Halle especially Dr Mika Tarkka, Dr Thomas Reitz, Kerstin Hommel and Professor François Buscot for their considerable assistance notably the hosting of the research and sequencing of the strains. We are grateful to Mrs. Sawsan Abdelrahman, Mr. Abdelwahab Magzoub, Ahmed Sulieman Abdulaleem and Sheikh Hamad for help with soil sample collection.

\section{Authors' contributions}

MEH, MAIH and MME conceived and designed the study. AM and L. C. C. performed experiments. MRPJ, AGO, and HAE participated with data collection and experimental; MAlH and MME supervised and participated in manuscript writing; $\mathrm{MEH}$ analyzed the data and wrote the manuscript. All authors read and approved the final manuscript.

\section{Funding}

This work was supported by a fellowship from Alexander von Humboldt Foundation, Bonn, Germany (MEH).

\section{Availability of data and materials}


All data generated or analyzed during this study are included in this published article and DNA sequence data have been kept in GenBank of the National Centre for Biotechnology Information (NCBI) as and accessions numbers are available in the article table.

Ethics approval and consent to participate

This research did not involve human participants, or the collection of human data or human tissue, and it did not involve animals. Accordingly, this research was not subject to ethics approval and consent to participate.

Consent for publication

Not applicable.

Competing interests

The authors declare that they have no competing interest.

\section{References}

1.Barka EA, Vatsa P, Sanchez L, Gaveau-Vaillant N, Jacquard C, Meier-Kolthoff JP, Klenk HP, Clement C, Ouhdouch Y, van Wezel GP: Taxonomy, Physiology, and Natural Products of Actinobacteria. Microbiology and molecular biology reviews: MMBR 2016, 80(1):1-43.

2.Kämpfer P: Family Streptomycetaceae. In: Bergey's Manual of Systematic Bacteriology Volume 5: The Actinobacteria. Edited by Whitman MGW, Kämpfer P, Busse H, Trujillo M, Ludwig W, Suzuki K, (editors) AP. New York: Springer-Verlag 2012.

3.Kumar RR, Jadeja VJ: Isolation of Actinomycetes: A Complete Approach. International Journal of Current Microbiology and Applied Sciences 2016, 5:606-618.

4.Gerber NN, Lechevalier HA: Geosmin, an earthly-smelling substance isolated from actinomycetes. Applied microbiology 1965, 13(6):935-938.

5.McCarthy AJ, Williams ST: Actinomycetes as agents of biodegradation in the environment-a review. Gene 1992, 115(1-2):189-192.

6.Cumsille A, Undabarrena A, Gonzalez V, Claverias F, Rojas C, Camara B: Biodiversity of Actinobacteria from the South Pacific and the Assessment of Streptomyces Chemical Diversity with Metabolic Profiling. Marine drugs 2017, 15(9).

7.Das R, Romi W, Das R, Sharma HK, Thakur D: Antimicrobial potentiality of actinobacteria isolated from two microbiologically unexplored forest ecosystems of Northeast India. BMC microbiology 2018, 18(1):71. 
8.Khattab A, Babiker EH, Humodi A. Saeed HA: Streptomyces: isolation, optimization of culture conditions and extraction of secondary metabolites. International Current Pharmaceutical Journal 2016, 5.27-32.

9. Hamza AA, Ali HA, Clark BR, Murphy CD, Elsheikh A. Elobaid EA: Isolation and characterisation of actinomycin D producing Streptomyces spp. from Sudanese soil. African Journal of Biotechnology 2013, $12.2624-2632$.

10.Davelos AL, Xiao K, Samac DA, Martin AP, Kinkel LL: Spatial variation in Streptomyces genetic composition and diversity in a prairie soil. Microbial ecology 2004, 48(4):601-612.

11. Harrison MN, Jackson JK: Ecological Classification of the Sudan. Ministry of Agriculture, Sudan: Forest Department, Forest Bulletin No. 2.; 1958.

12.Jones A, Breuning-Madsen H, Brossard M, Dampha A, Deckers Dewitte O, Gallali T, Hallet S, Jones R, Kilasara M, Le Roux P et al: Soil Atlas of Africa. Luxembourg: European Commission, Publications Office of the European Union. ISBN 978-92-79-26715-4, doi 10.2788/52319; 2013.

13. Nonomura $\mathrm{H}$, Hayakawa M: New methods for the selective isolation of soil actinomycets. In: Biology of Actinomycetes'88. Edited by Okami Y. Tokyo, Japan: Japan Scientific Societies Press; 1988 288-293.

14.Shirling EB, Gottlieb D: Methods for characterization of Streptomyces species. Int J Syst Bacteriol $1966,16.313-340$.

15.Williams ST, Cross T: Actinomycetes, methods in microbiology, vol 4. . New York: Academic Press; 1971.

16.Lane DJ, Stackebrandt E, Goodfellow M: 6S/23S rRNA sequencing. In: Nucleic Acid Techniques in Bacterial Systematics. New York: John Wiley \& Sons; 1991.

17.Rainey FA, Ward-Rainey N, Kroppenstedt RM, Stackebrandt E: The genus Nocardiopsis represents a phylogenetically coherent taxon and a distinct actinomycete lineage: proposal of Nocardiopsaceae fam. nov. International journal of systematic bacteriology 1996, 46(4):1088-1092.

18.Lane DJ: 16S/23S rRNA sequencing. In: Nucleic acid techniques in bacterial systematics. Edited by Stackebrandt E, Goodfellow M. Chichester; New York: Wiley; 1991: pp. 115-175.

19.Saitou N, Nei M: The neighbor-joining method: a new method for reconstructing phylogenetic trees. Molecular biology and evolution 1987, 4(4):406-425.

20.Tamura K, Stecher G, Peterson D, Filipski A, Kumar S: MEGA6: Molecular Evolutionary Genetics Analysis version 6.0. Molecular biology and evolution 2013, 30(12):2725-2729.

21.Kumar S, Stecher G, Tamura K: MEGA7: Molecular Evolutionary Genetics Analysis Version 7.0 for Bigger Datasets. Molecular biology and evolution 2016, 33(7):1870-1874. 
22.Burgess ND, Hales JD, Underwood E, Dinerstein E: Terrestrial ecoregions of Africa and Madagascar: a conservation assessment. Washington DC: Island Press; 2004.

23.Pasternak Z, Al-Ashhab A, Gatica J, Gafny R, Avraham S, Minz D, Gillor O, Jurkevitch E: Spatial and temporal biogeography of soil microbial communities in arid and semiarid regions. PloS one 2013, 8(7):e69705.

24.Bull AT, Asenjo JA: Microbiology of hyper-arid environments: recent insights from the Atacama Desert, Chile. Antonie van Leeuwenhoek 2013, 103(6):1173-1179.

25.Neilson JW, Califf K, Cardona C, Copeland A, van Treuren W, Josephson KL, Knight R, Gilbert JA, Quade J, Caporaso JG et al: Significant Impacts of Increasing Aridity on the Arid Soil Microbiome. mSystems $2017,2(3)$.

\section{Figures}



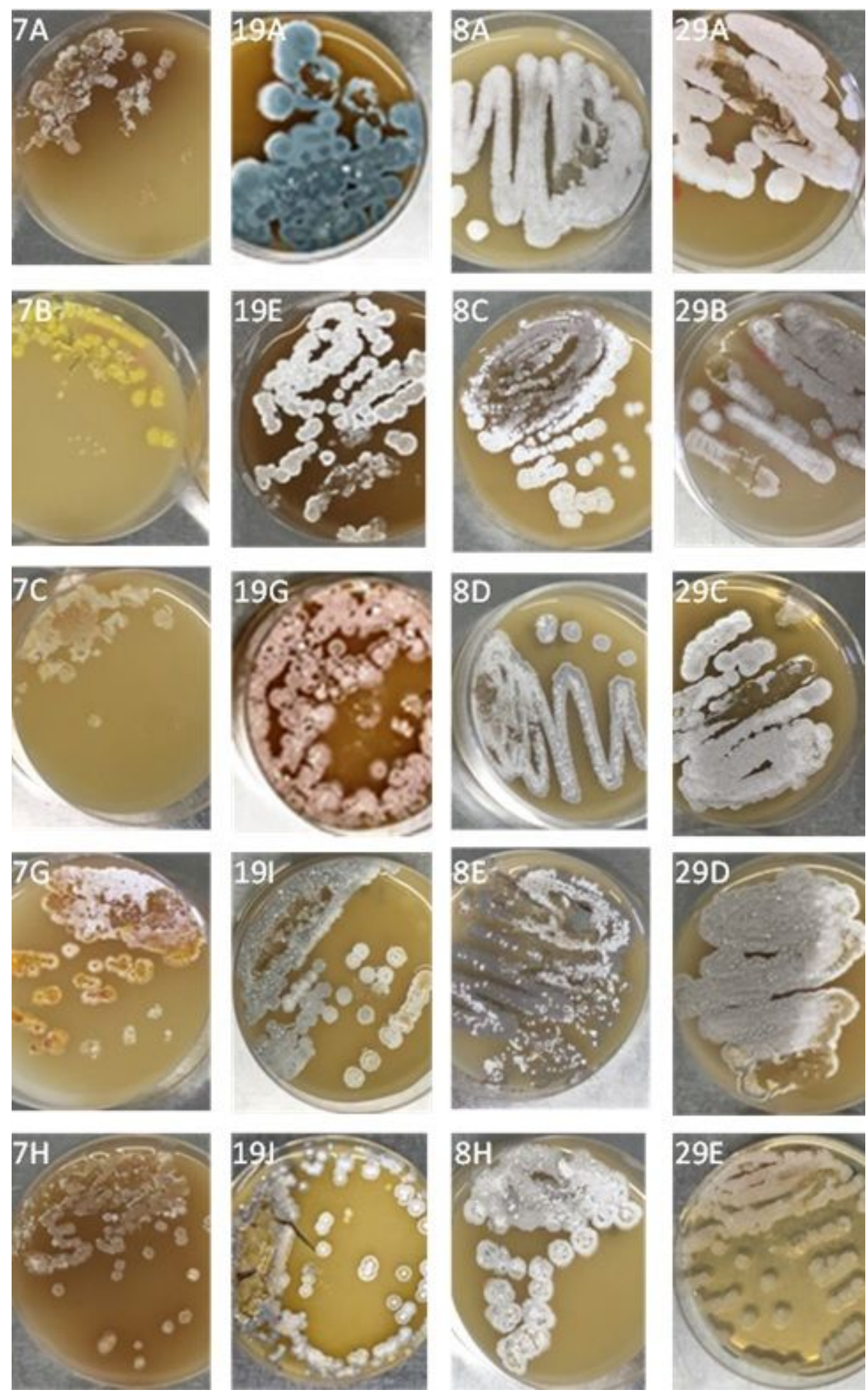

\section{Figure 1}

Colony morphology of Streptomyces spp. isolated from desert and savanna soils in Sudan using ISP2 medium, incubated at $280 \mathrm{C}$ for 15 days (plat number indicated soil sits and letter indicates phenotype). 


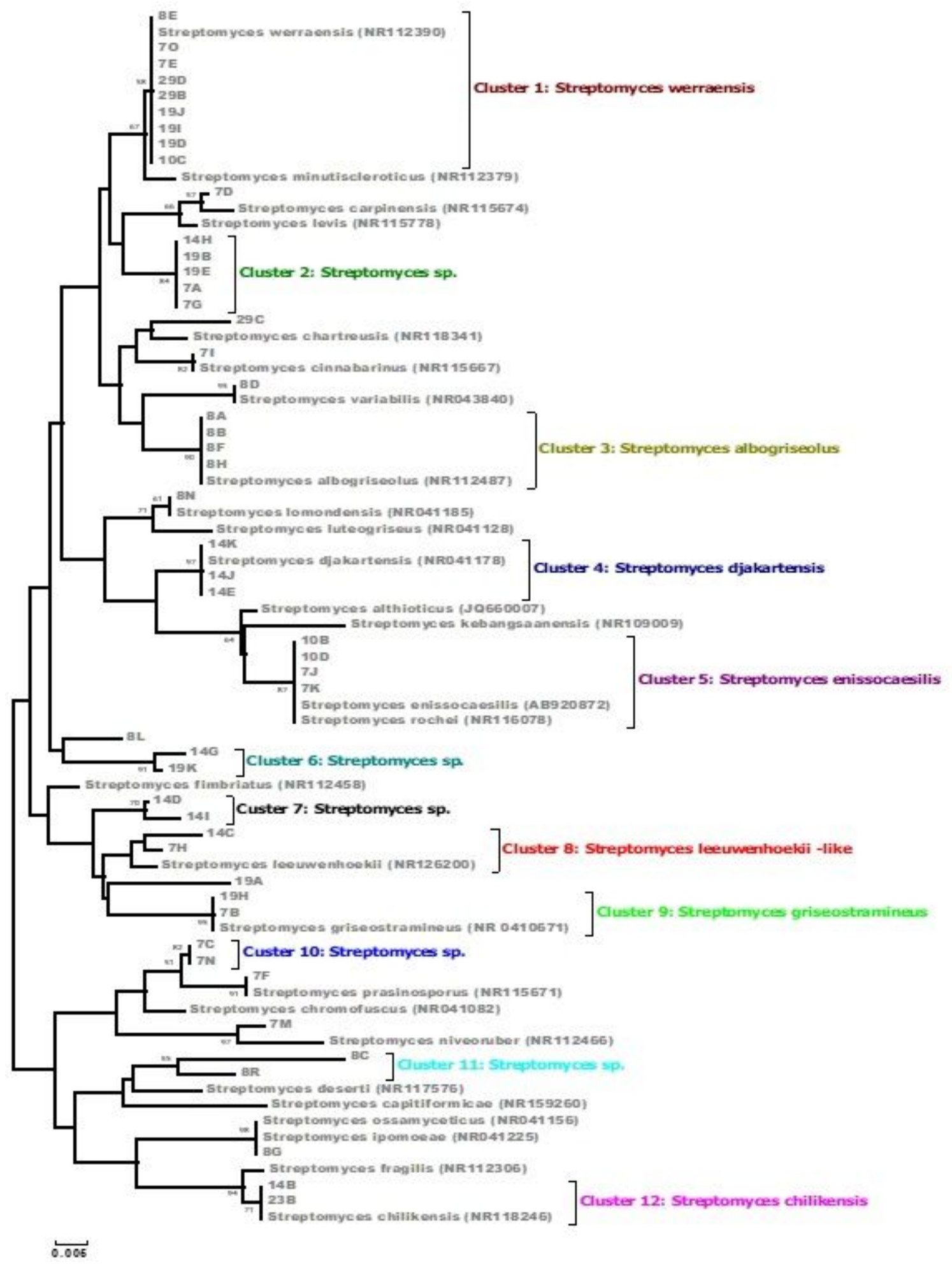

Figure 2

Phylogenetic relationships based on 16S rRNA sequences amongst 49 Streptomyces strains in relationship o closely related validly described species. Evolutionary analysis was based on the Neighborjoining method using MEGA7 software [21]. 